\title{
PERKEMBANGAN MATEMATIKA DALAM FILSAFAT DAN ALIRAN FORMALISME YANG TERKANDUNG DALAM FILSAFAT MATEMATIKA
}

\author{
Lily Parnabhhakti ${ }^{1}$, Marchamah Ulfa ${ }^{2}$ \\ Universitas Teknokrat Indonesia ${ }^{\mathbf{1 , 2}}$ \\ lilyparnabhakti@gmail.com
}

\begin{abstract}
Mathematics and philosophy have a pretty close relationship, compared to other sciences. The reason, philosophy is the base for learning science and mathematics is the mother of all sciences. There are also those who think that philosophy and mathematics are the mother of all existing sciences. In historical terms, the relationship between philosophy and mathematics experienced a very striking development. The question arises regarding "Is mathematics an abstract science?" "What is the origin of the formation of numbers?" And questions that are difficult to be solved by mathematics itself. Therefore we need a field of science that can bridge and accommodate questions that arise. Therefore, the field of philosophy has emerged which is able to answer matters concerning the history and development of mathematics itself. This research explains some of the problems surrounding what efforts need to be made to overcome the crisis, contradictions and paradoxes in mathematics and answer the basic questions of mathematical philosophy which currently widely used to teach and develop mathematics.
\end{abstract}

Keywords: philosophy mathematics, evolution of mathematics

\begin{abstract}
Abstrak
Ilmu matematika dan filsafat mempunyai keeratan hubungan dibandingkan keilmuan lainnya. Karena matematika dan filsafat sama-sama merupakan fondasi dari semua jenis keilmuan. Terdapat juga pendapat bahwa matematika dan filsafat merupakan ibunya ilmu pengetahuan. Menilik pada sisi hisotris, korelasi matematika dan filsafat mengalami perkembangan yang sangat menyolok. Munculnya pertanyaan mengenai "Apakah matematika merupakan ilmu yang bersifat abstrak?". "Bagaimana asal mula terbentuknya bilangan?" serta pertanyaan yang sulit untuk dipecahkan oleh matematika itu sendiri. Oleh karena itu dibutuhkan suatu bidang ilmu yang dapat menjembatani serta mewadahi pertanyaan- pertanyaan yang muncul. Maka sebab itu muncullah bidang filsafat yang mampu menjawab hal-hal mengenai asal mula maupun perkembangan matematika itu sendiri Artikel ini menjelaskan usaha untuk mengatasi krisis, pernyataan kontradiktif serta paradok pada ilmu matematika. Selain itu, artikel ini juga berusaha menjawab pertanyaan filasafat yang diterapkan untuk pengembangan ilmu matematika.
\end{abstract}

Kata Kunci: filsafat matematika, perkembangan matematika

Sitasi artikel ini:

Parnabhakti, L. \& Ulfa, M. (2020). Perkembangan Matematika dalam Filsafat dan Aliran Formalisme yang Terkandung dalam Filsafat Matematika. Jurnal Ilmiah Matematika Realistik (JIMR), 1(1), 11-14. 


\section{PENDAHULUAN}

Filsafat berasal dari bahasa Yunani yaitu phillein dan shopia yang artinya cinta dan kebijaksanaan. Berfilsafat akan membawa pada hakikat pengetahuan atau dengan kata lain dalam membawa pada pengetahuan yang paling dalam. Keraguan, ketidakpuasan, hasrat, dan ketakjuban merupakan empat hal yang mendorong orang dalam berfilsafat (Sukardjono, 2000). Menurut Korner dalam Prabowo (2009), pada filsafat matematika tidak terdapat penambahan teorema atau teori baru matematika, oleh karena itu filsafat matematika tidak dapat dikatakan sebagai ilmu matematika. Filasfat matematika dapat dikatakan sebagai refleksi terhadap ilmu matematika yang mengakibatkan hadirnya pertanyaan dan jawaban tertentu. Menurut P. Hilton (Gunawan, 2007), adanya hasrat manusia untuk mensistemasikan pengalaman hidup merupakan asal usul dari lahir dan berkembangnya ilmu matematika. Manusia ingin menata dan lebih mamahami kehidupan sehingga pada suatu titik, manusia ingin agar bisa meramalkan dan mengendalikan kejadian atau peristiwa di masa depan.

Banyak kemampuan yang bisa dikembangkan dari pembelajaran matematika, antara lain penyelesaian masalah, komunikasi matematis, dan koneksi matematis. Selain itu, kemampuan yang bisa dikembangkan melalui pembelajaran matematika adalah kemampuan berpikir (Puspaningtyas, 2019). Pengembangan filsafat matematika diawali oleh isu-isu eksternal diantaranya asal-usul, sejarah, serta praktek matematika dalam pemodelan matematika menggunakan pendekatan budaya. Maskar \& Anderha (2019) memperkenalkan budaya pada siswa melalui pembelajaran di sekolah dengan cara mengintegrasikan budaya pada matematika.

Ontologi dan epistemologi merupakan isu-isu eksternal tersebut. Kriteria kecukupan filsafat matematika merupakan salah satu aliran yang diguankan untuk mengklarifikasi aliran-aliran dalam filsafat matematika. Kriteria tersebut meliputi pengetahuan matematika diantaranya sifat, justifikasi, dan asal-usul dari penetahuan. Kemudian obyek matematika yang memuat ruang lingkup serta asal-usul obyek matematika. Selanjutnya aplikasi matematika yang memahas tentang efektifitas matematika di dalam pengembangan teknologi, sains, serta aplikasi lainnya. Terakhir, praktek matematika; mmbahas tentang aktivitas pelaku matematika atau matematikawan dari dulu sampai dengan sekarang (Ernest dalam Prabowo, 2009).

Menurut Puspaningtyas (2019), menyelesaikan soal matematika menggunakan konteks sangat penting digunakan dalam pembelajaran karena merupakan suatu cara yang dapat dilakukan untuk membantu menggunakan kemampuan matematikanya dalam kehidupan sehari-hari. Terdapat beberapa ahli yang memberikan pendapat dan analisanya terhadap pengertian matematika, diantaranya Wikins, Whitehead, Boole, Kant, Von Neumann, Riemann, Kaplansky, Weyl, dan Hilbert. Wilkins tidak terlalu yakin dan pasti tentang makna dari matematika, karena menurutnya banyak definisi tentang matematika. Kemudian Whitehead, seorang ahli logika, menyatakan bahwa matematika merupakan bentuk formal dari seluruh ilmu pengetahuan yang ada yang bersifat deduktif. Boole mempunyai pendapat lain, Ia menyatakan bahwa matematika merupakan kumpulan ide tentang jumlah dan kuantitas. Kant dan Von Neumann memberikan pendapat bahwa ilmu matematika adalah contoh ilmu yang paling luar biasa (cemerlang) karena menggabungkan akal murni dengan bantuan pengalaman dengan sangat baik. Sedangkan Riemann memberikan pendapat dengan menggunakan konsep matematika itu sendiri, Ia menyatakan bahwa apabila Ia memiliki teorema yang tepat, itu akan memudahkan untuk menunjukan buti makna dari matematika. Kaplansky sebaliknya, Ia mengemukakan bahwa dalam matematika yang menarik adalah bukan pada saat pembuktian atau ketika terlah berhasil membuktikan suatu teorema, namun pada penemuan konsep baru. Weyl mengemukakan bahwa matematika dapat membuktikan adanya Tuhan dan iblis. Kekonistenan matematika membuktikan adanya Tuhan, sedangkan Iblis dibuktikan karena tidak seorangpun dapat membuktikan kekonsistenan tersebut secara sahih. Kemudian Hibert menyimpulkan matematika sebagai suatu kesatuan ilmu yang konsisten. Kekonsistenan kesatuan ilmu tersebut ditunjukan oleh sebuah sistem atau strutukur yang dibentuk oleh hubungan-hubungan antar bagiannya, penyederhanaan metode, serta pembaruan prosedur dengan cara menghilangkan prosedur lama seiring dengan ditemukannnya konsep baru. Aliran filsafat matematika muncul akibat adanya beberapa informasi dari beberapa ilmuan oleh karena itu artikel ini ditulis dengan tujuan menginformasikan kembali topik matematika lama yang kurang populer.

\section{METODE PENELITIAN}

Penulis mengunakan Metode deskriptif. dengan menyajikan gambaran, klarifikasi mengenai suatu fenomena dan fakta dalam matematika. Serta studi pustaka (library research). Dengan mengumpulkan beberapa artikel serta pendapat para ahli mengenai filsafat matematika yang kemudian di kembangkan dengan berbagai penemuan yang ada. Hasil penelitian ini dapat dijadikan sebagai acuan ataupun referensi untuk mencari informasi mengenai perkembangan matematika dalam ilmu filsafat. 


\section{HASIL DAN PEMBAHASAN}

Matematika adalah ilmu yang kebenarannya mutlak, tidak dapat direvisi karena didasarkan pada deduksi murni yang merupakan kesatuan sistem dalam pembuktian matematika. Sistem deduksi itu menjelaskan bahwa dalam pembuktikan mateamtika, suatu proposisi dinyatakan bernilai benar apabila aksioma atau postulat yang mendasarinya juga benar. Matematika merupakan salah satu cabang ilmu pengetahuan yang dipelajari di sekolah. Pelajaran matematika tidak melulu tetang angka, tetapi jauh lebih dalam dari itu (Puspaningtyas, 2019). Kesahihan dalam ilmu matematika dikembangkan dengan tujuan bukan untuk diterapkan dalam kehidupan nyata. Berdasarkan pernyataan Einstein (Sriasumantri, 2005) bahwa apabila suatu hukum matematika mengacu pada realitas, huku tersbut menjadi tidak pasi, dan sebaliknya apabila hukum tersebut pasti, artinya tidak mengacu pada realitas. Aliran formalisme memberikan gambaran bahwa matematika hanya sekedar rekayasa dari simbol-simbol berdasarkan suatu aturan tertentu sehingga menghasilkan suatu sistem pernyataan tautologis yang konsisten dan tidak mempunyai makna. Selain itu, matematika memberikan kemampuan penyelesaian masalah secara logis, kritis, sistematis dan kreatif (Ulfa, 2019). Permainan catur merupakan salah satu permainan intelektual hasil dari tuurnan ilmu matematika. Berdasarkan aliran formalisme, matematika adalah sebuah permainan formal dengan makna menggunakan lambang atau simbol-simbol dengan aturan tertentu.

Van Den Heuvel dalam Maskar (2018) berpendapat bahwa pembelajaran matematika harus terhubung dengan realitas, terdapat pada kehdupan sehari-hari dan dekat anak-anak serta relevan dengan nilai yang terdapat pada masyarakat. Pemodelan matematika tidak dapat menangani masalah yang berubah secara tiba-tiba, oleh karena itu pendekatan matematika pada dunia nyata cenderung bersifat kasar. Seperti dalam Saputra \& Febriyanto (2019) menyatakan bahwa bilangan adalah sesuatu yang tidak dapat dilihat, ditulis, dibaca dan dikatakan, karena bilangan merupakan suatu idea yang hanya dapat dihayati atau dipikirkan saja, maka diperlukan adanya simbol ataupun lambang yang digunakan untuk mewakili suatu bilangan yang disebut sebagai angka. Hasil-hasil perkembangan matematika kontemporer memperlihatkan adanya perkembangan yang sama sekali keluar dari jalur formalisme, meskipun hasil-hasil tersebut disajikan dengan menggunakan logika dalam bentuk sistem aksiomatik milik kaum Formalis. Secara tidak langsung ini memperlihatkan penerimaan kaum Formalis atas perkembangan kontemporer matematika atau mengindikasikan telah terjadinya revisi diam-diam atas fondasi matematika kaum Formalis.

Perubahan mendadak yang tidak dapat digambarkan oleh rumus matematika klasik, sebuah perubahan yang melibatkan patahan-patahan dalam rangkaian perubahan yang kontinum, suatu bentuk ketakberaturan matematis yang ditemukan dalam dunia nyata.

Seiring waktu dan perkembangan matematika, cakupan matematika makin meluas. Dalam hubungan matematika dan filsafat ini maka dibagilah bidang bidang filsafat matematika. Pembagian berikut ini telah sistematis yaitu:

1. Epistemologi Matematika Tujuan pengetahuan dalam hal ini adalah matematika, yang merupakan reflesi pikiran dari pengetahuan, asal usul, sifat alami, batas, dasar dan asumsi, prinsip validitaas dan reliabilitas.

2. Ontologi Matematika Pembahasan mengenai apa yang ada di dalam matematika. Tercakup di dalamnya pernyataan pernyataan matematika.

3. Metodologi Matematika Mencakup metoda apa yang digunakan dalam matematika. Dalam hal ini dikenal dua metoda spesial yaitu metoda aksiomatik (axiomatic method) dan metode hipotetik deduktif (hipothetical-deductive method).

4. Logical Structure Struktur logika yang melingkupi kesatuan struktur logis. Dalam hal ini haru disajikan sebuah kesimpulan yang logis dalam penulisan pengetahuan matematika.

5. Implikasi Etis Tentang penerapan matematika ilmiah sesuai pribadi individual dalam melakukan perhitungan angka dan aplikasi teorema dan rumus. Ini berkaitan erat dengan impliaksi tingkah laku manusia yang bersifat etis, contoh perkembangan teknik teknik dalam statistik. Semakin hari ini akan semakin rumit menimbang banyaknya faktor penyebab lain yang berkembang juga. Bagaimana perkembangan manusia secara etis dan penerapan matematika di dalamnya, ini yang menjadi permasalahan filsafat matematika secara estetis.

\section{SIMPULAN}

Matematika dan filsafat sama-sama mempunyai daya tarik yang kuat pada saat zaman Yunani kuno. Ilmu matematika banyak menginspirasi filusuf Yunani untuk mendeskripsikan pemikiran filsafat. Hubungan yang erat antara matematika dan filsafat menurunkan ilmu pengetahuan baru. Oleh karena itu, perlunya menguasi 
mateamtika dan filsafat sebagai dasar untuk memecahkan masalah yang tidak dapat dipecahkan oleh logika semata.

\section{REFERENSI}

Prabowo, A. (2009). Aliran- Aliran Filsafat Dalam Matematika. Jurnal Ilmiah Matematika dan Pendidikan Matematika (JMP). 1(2). 26-44.

Gunawan, H. (2007). Pidato Pengukuhan Guru Besar ITB. Tersedia online: http://personal.fmipa.itb.ac.id/.../naskah-pidatoilmiah-gb-itb-hendra-g-v3.pdf

Sukardjono. (2000). Filsafat dan Sejarah Matematika. Jakarta: Universitas Terbuka.

Suriasumantri, J.S. (2005). Filsafat Ilmu: Sebuah Pengantar Populer. Pustaka Sinar Harapan

Maskar, S. \& Anderha, R. R. (2019). Pembelajaran Transformasi Geometri dengan Pendekatan Motif Kain Tapis Lampung. Mathema: Jurnal Pendidikan Metematika. 1(1), 40-47

Maskar, S. (2018). Alternatif Penyusunan Materi Ekspresi Aljabar untuk Siswa SMP/MTs dengan Pendekatan Pendidikan Matematika Realistik. PRISMA. 7(1), 53-69

Puspaningtyas, N. D. (2019). Berpikir Lateral Siswa SD dalam Pembelajaran Matematika. Mathema: Jurnal Pendidikan Matematika. 1(1), 25-30

Ulfa, Marchamah. (2019). Strategi Preview, Question, Read, Reflect, Recite, Review (PQ4R) pada Pemahaman Konsep Matematika. Mathema: Jurnal Pendidikan Metematika. 1(1), 48-55

Saputra, V.H. \& Febriyanto, E. (2019). Media Pembelajaran Berbasis Multimedia Untuk Anak Tuna Grahita. Mathema: Jurnal Pendidikan Matematika. 1(1), 15-23 